\title{
Identification of the Prosthetic Group and Further Characterization of a Novel Enzyme, Polyethylene Glycol Dehydrogenase
}

\author{
Fusako Kawai, Hiroshi YamanaKa, Minoru Ameyama,* \\ Emiko Shinagawa, ${ }^{*}$ Kazunobu Matsushita* \\ and Osao AdACHI* \\ Department of Biology, Kobe University of Commerce, \\ Kobe 655, Japan \\ *Department of Agricultural Chemistry, Yamaguchi University, \\ Yamaguchi 753, Japan
}

Received August 30, 1984

\begin{abstract}
The purified polyethylene glycol (PEG) dehydrogenase from cells of a synergistic mixed culture of Flavobacterium and Pseudomonas species showed a similar absorption spectrum to those of other quinoproteins reported so far. The prosthetic group of the PEG dehydrogenase after extraction with cold methanol and purification by DEAE-Sephadex A-25 column chromatography and Sephadex G-25 gel filtration showed the same elution profiles as those of authentic pyrroloquinoline quinone (PQQ). Absorption and fluorescence spectra of the purified prosthetic group and its prosthetic group capability for glucose dehydrogenase indicated that it was identical with authentic PQQ.

The enzyme was induced during bacterial cell growth on a medium containing.PEG 6000 as a sole source of carbon. The purified enzyme oxidized primary alcohols of $\mathrm{C}_{2}-\mathrm{C}_{16}$ and the corresponding aldehydes of $\mathrm{C}_{4}-\mathrm{C}_{7}$. The enzyme also reacted with nonionic surfactants containing PEG residues. The enzyme reduced 2,6-dichlorophenolindophenol (DCIP) and the $\mathrm{Km}$ value for DCIP was calculated to be $1.4 \times 10^{-4} \mathrm{M}$. The DCIP reductase activity was inhibited by carbonyl reagents like semicarbazide, hydrazine, hydroxylamine and 1,4-benzoquinone. 1,4-Benzoquinone inhibited the DCIP reductase activity competitively as to DCIP.
\end{abstract}

An increasing number of reports on quinoproteins which include pyrroloquinoline quinone (PQQ) as the prosthetic group have appeared. The quinoproteins so far reported are: Methanol dehydrogenase from methylotrophs, ${ }^{1)}$ alcohol, ${ }^{2,3)}$ aldehyde ${ }^{2,4)}$ and glycerol $^{5)}$ dehydrogenases from acetic acid bacteria, glucose dehydrogenase from acetic acid bacteria ${ }^{2,6)}$ and other oxidative bacte$\mathrm{ria}^{2,7)}$ and methylamine dehydrogenase from methylotrophic bacteria. ${ }^{8}$ Recently, copper containing amine oxidases of mammalian and microbial origins, the prosthetic groups of which had been controversial, were proved to be quinoproteins in which PQQ was tightly bound to the enzyme proteins via covalent bonds. ${ }^{9)}$ Later, Duine et al. ${ }^{10)}$ also reported the same results. Two types of PQQ bindings are known, one of which is through a noncovalent bond and the other is covalent binding to the enzyme protein like the case of flavin in flavoproteins. The former type of PQQ can be readily released from the enzyme protein by methanol extraction. On the other hand, proteolytic digestion and acid hydrolysis are required to release a reasonable amount of PQQ from the latter. The prosthetic group thus released from the enzymes has been proved to be identical with authentic PQQ. Thus, the quinoproteins have been recognized to be involved in many kinds of enzymes of metabolic importance. In the previous papers, ${ }^{11 \sim 13)}$ the formation, purification and characterization of a novel enzyme, polyethylene glycol (PEG) dehydrogenase, from a synergistic mixed culture of Flavobacterium and Pseudomonas species, were reported. Kawai et al. found that oxidative degradation 
is common to the metabolism of PEG by aerobic bacteria, and PEG-oxidizing enzymes (DCIP-dependent and independent) are present in cell-free extracts of other PEG-utilizing bacteria. $^{14,15)}$ Judging from the enzymatic function, the enzyme must be localized in the periplasmic space or on the outer surface of the cytoplasmic membrane of the organisms, like the other quinoproteins. An attempt was made to clarify whether the enzyme contains PQQ as the prosthetic group. In this paper, isolation, purification and characterization of the isolated coenzyme are described and the identity of the prosthetic group with PQQ is also discussed. In addition, this paper deals with further characterization of the enzyme as to the enzyme induction, substrate specificity and inhibition of 2,6-dichlorophenolindophenol (DCIP) reductase activity.

\section{MATERIALS AND METHODS}

Materials. Laurylbetaine used for enzyme purification was a kind gift from Kao-Atlas Co., Ltd., Tokyo, and the Epan series (PEG-polypropylene glycol copolymers) used for enzyme characterization was kindly donated by Daiichi Kogyo Seiyaku Co., Ltd. We are also grateful to Eizai Co. for kindly supplying the coenzyme $Q$ series. Futhentic PQQ was prepared according to the method described previously. ${ }^{9)}$ Other chemicals used in this study were of commercial grade.

Microorganisms and cultivation. A synergistic mixed culture (Flavobacterium and Pseudomonas species) was used throughout this study: The mixed culture can grow on PEG of various molecular weights $\left(M_{n}, 400 \sim 20,000\right)$, but usually it was cultivated on PEG 6000 as described previously. ${ }^{13)}$

Enzyme preparation and assaying of enzyme activity. Purification of the enzyme was performed according to the previous papers. ${ }^{12,13)}$ The enzyme activity was assayed by measuring the initial rate of DCIP reduction and the unit was defined as described previously. ${ }^{13)}$

Analytical procedures. Absorption spectra were measured with a Hitachi 200-10 spectrophotometer. Fluorescence spectra were measured with a Hitachi 650-10S fluorescence spectrophotometer at $25^{\circ} \mathrm{C}$ with excitation at $365 \mathrm{~nm}$ and emission at $465 \mathrm{~nm}$ under essentially the same conditions as reported previously. ${ }^{9)}$ Enzymatic identification of PQQ was performed by measuring activation of apoglucose dehydrogenase as reported elsewhere. $^{2)}$

\section{RESULTS AND DISCUSSION}

Absorption spectrum of the purified enzyme

The absorption spectrum of the enzyme showed two peaks at $350 \mathrm{~nm}$ and $440 \mathrm{~nm}$ in the visible region, as shown in Fig. 1. These absorption maxima were similar to those of other quinoprotein enzyme species, such as methanol dehydrogenase, ${ }^{16)}$ alcohol dehydrogenase ${ }^{3)}$ methylamine dehydrogenase ${ }^{17)}$ and aromatic amine dehydrogenase. ${ }^{18)}$

\section{Extraction and purification of the prosthetic group}

To the purified enzyme ( $3 \mathrm{mg}$ pure enzyme as estimated from the electrophoretic profile), cold methanol was added to $90 \%$ and the solution was stirred gently for two days at $4^{\circ} \mathrm{C}$. The coagulated proteins were separated by precipitation in a high speed centrifuge at $10,000 \times g$ for $10 \mathrm{~min}$. The supernatant was evaporated in vacuo at $30^{\circ} \mathrm{C}$ in a rotary evaporator to remove methanol. The pale yellow solution was then applied to a DEAESephadex A-25 column $(1 \times 10 \mathrm{~cm})$, which had been equilibrated with $0.002 \mathrm{M}$ potassium

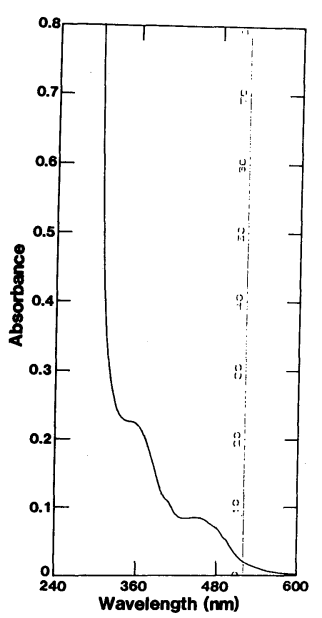

Fig. 1. Absorption Spectrum of the Purified PEG Dehydrogenase.

A concentrated enzyme solution containing $6.3 \mathrm{mg}$ protein $/ \mathrm{ml}$ in buffer $\mathrm{B},{ }^{13}$ ) with a specific activity of 0.23 units $/ \mathrm{mg}$, was analyzed at room temperature. 


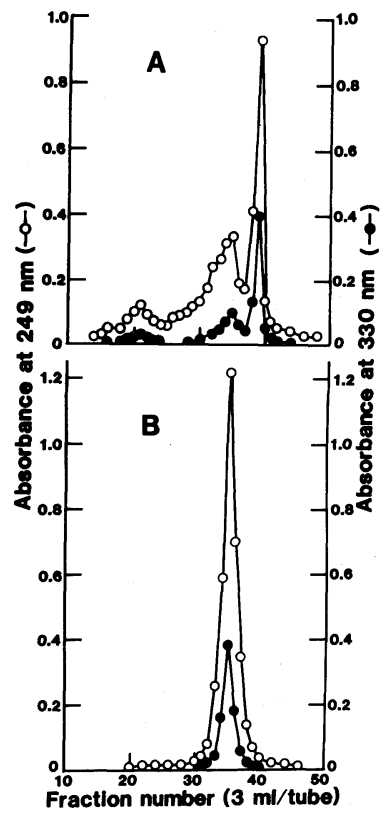

FIG. 2. Elution Profiles of the Isolated Prosthetic Group and Authentic PQQ on a Sephadex G-25 Column.

A concentrated solution of the isolated prosthetic group $(2 \mathrm{ml})$ was applied onto a Sephadex column $(1 \times 180 \mathrm{~cm})$ and $3 \mathrm{ml}$ fractions were collected (A). Authentic PQQ was subjected to gel filtration under the same conditions as for the isolated prosthetic group (B). Elution was monitored by reading the absorbance at $249 \mathrm{~nm}(\mathrm{O})$ and $330 \mathrm{~nm}(\odot)$.

phosphate, $\mathrm{pH}$ 7.0. After washing the column with the same buffer, the column was treated with the same buffer containing $\mathrm{KCl}$. A minor contaminant was almost removed with $0.1 \mathrm{M}$ $\mathrm{KCl}$. When elution was monitored by reading the absorbance at the dual wavelengths of 249 and $330 \mathrm{~nm}$, the major intense absorbance was found in the fraction eluted with $1 \mathrm{M}$ $\mathrm{KCl}$, though a minor elution peak was observed with $0.5 \mathrm{M} \mathrm{KCl}$. These chromatographic profiles were identical with those of authentic PQQ. The spectral properties and prosthetic group capability for glucose dehydrogenase were also confirmed with these fractions. The fractions including PQQ were pooled and concentrated to about $2 \mathrm{ml}$. The concentrated solution was separated from solid $\mathrm{KCl}$ by centrifugation and applied to a column of Sephadex G-25 $(1 \times 180 \mathrm{~cm})$, which had been washed with distilled water. Three milliliter

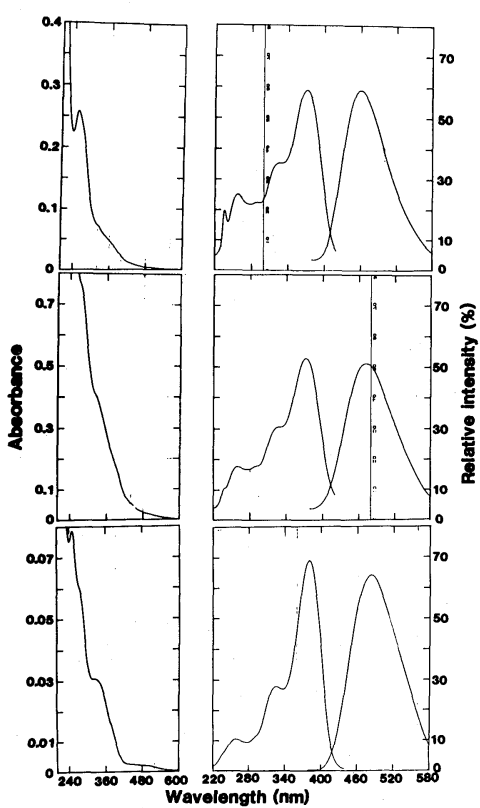

FIG. 3. Absorption and Fluorescence Spectra of the Isolated Prosthetic Group and Authentic PQQ.

Absorption spectra are shown in the left column. Upper frame, fraction number 35 from gel filtration shown in Fig. 2; middle frame, fraction number 40; bottom frame, authentic PQQ $(2 \mu \mathrm{g} / \mathrm{ml})$. Fluorescence spectra are shown in the right column.

fractions were collected at a flow rate of one drop per $15 \mathrm{sec}$. The elution profiles obtained with the isolate and authentic PQQ are shown in Fig. 2. The maximal PQQ activity was found around fraction number 35 that corresponded to the elution position of authentic PQQ. Another PQQ activity was also seen at fraction number 40 where excess $\mathrm{KCl}$ was eluted. About $2.5 \mu \mathrm{g} / \mathrm{ml}$ of PQQ and $5.2 \mu \mathrm{g} / \mathrm{ml}$ of PQQ were present in fraction numbers 35 and 40 , respectively, when assayed enzymatically.

\section{Spectral properties of the isolated prosthetic group}

Absorption and fluorescence spectra of the purified prosthetic group were measured. As shown in Fig. 3, the spectral similarity of the purified prosthetic group to authentic PQQ was proved. Absorption spectra of the prosthetic group showed two shoulders at 350 


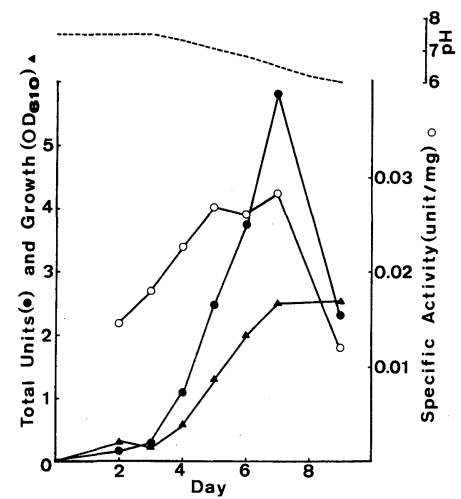

FIG. 4. Changes in PEG Dehydrogenase Activity during Cell Growth.

The mixed culture was cultured at $28^{\circ} \mathrm{C}$ in several 2-liter flasks containing $500 \mathrm{ml}$ of liquid medium with the same inoculum size. Cell growth was turbidimetrically measured as optical density (OD) of the culture at $610 \mathrm{~nm}$. The enzyme activity of a cell-free extract was assayed by measuring the initial rate of DCIP reduction as described in Materials AND Methods. Symbols: $\boldsymbol{\Delta}$, growth; ---, $\mathrm{pH} ; \mathrm{O}$, specific activity; $\mathbf{O}$, total activity.

and $270 \mathrm{~nm}$. The absorption peak at $249 \mathrm{~nm}$ was also detected for both fraction numbers 35 and 40 . The fluorescence spectra of the isolated fractions were identical with those of authentic PQQ. The excitation maxima were found at 260,320 and $370 \mathrm{~nm}$ as in the case of authentic PQQ. The emission peak was also seen around 460 to $480 \mathrm{~nm}$. These results indicated the complete coincidence of the isolated prosthetic group with authentic PQQ.

The results obtained showed that the enzyme, PEG dehydrogenase, contains PQQ as the prosthetic group which is noncovalently bound to the enzyme and readily released from the enzyme by methanol extraction.

\section{Enzyme formation during cell growth}

PEG dehydrogenase activity increased with cell growth and reached a maximum in the late exponential growth phase, but it rapidly decreased in the stationary phase (Fig. 4). Judging from this result and the ratio of the two bacteria during cell growth as reported previously, ${ }^{11)}$ the enzyme must be an inducible one and be present in Flavobacterium sp.

\section{Table I. Relative Activity of the Enzyme} toward Primary AlCOHOlS

Enzyme activity was measured with the DCIP system as described in Materials AND METHODS. In the reaction mixture were the purified enzyme ( 0.03 units) and the substrates at the concentrations indicated in the table.

\begin{tabular}{llc}
\hline \multicolumn{1}{c}{ Substrate } & $\begin{array}{c}\text { Relative activity } \\
(\%)\end{array}$ \\
\hline PEG 6000 & $5.0 \mathrm{~mm}$ & 100 \\
1-Pentanol & $9.1^{a}$ & 223 \\
1-Octanol & $6.2^{a}$ & 204 \\
1-Nonanol & $5.6^{a}$ & 204 \\
1-Decanol & $5.1^{a}$ & 196 \\
1-Dodecanol & $4.3^{a}$ & 173 \\
1-Tetradecanol & $2.5^{b}$ & 262 \\
1-Hexadecanol & $2.5^{b}$ & 138 \\
\hline
\end{tabular}

a As these substrates were slightly soluble in water, $2 \mu \mathrm{l}$ of them were added to a reaction mixture. Their final concentrations were calculated to be $2 \mathrm{mg}$ / $2.5 \mathrm{ml}$.

b Methanol solution $(62.5 \mu \mathrm{mol} / \mathrm{ml}), 0.1 \mathrm{ml}$, which showed milky turbidity was used as the substrate.

\section{Table II. Relative Activity of The EnZyme TOWARD ALDEHYDES}

Enzyme activity was measured with the DCIP system described in Materials AND MeThODS. In the reaction mixture were the purified enzyme ( 0.09 units) and the substrates at the concentrations indicated in the table.

\begin{tabular}{lcc}
\hline \multicolumn{1}{c}{ Substrate $^{a}$} & & $\begin{array}{c}\text { Relative activity } \\
(\%)\end{array}$ \\
\hline PEG 6000 & $5.0 \mathrm{mM}$ & 100 \\
Formaldehyde & 13.3 & 0 \\
Acetaldehyde & 9.1 & 0 \\
1-Propanal & 6.9 & 0 \\
1-Butanal & 5.6 & 32 \\
1-Pentanal & 4.7 & 30 \\
1-Hexanal & 4.0 & 32 \\
1-Heptanal & 3.5 & 64
\end{tabular}

a One microliter of aldehydes was added to a reaction mixture. Their final concentrations were calculated to be $1 \mathrm{mg} / 2.5 \mathrm{ml}$.

\section{Characterization of the enzyme}

1) Substrate specificity. In the previous study, ${ }^{13)}$ it was found that the enzyme oxidized primary alcohols of $\mathrm{C}_{2}-\mathrm{C}_{7}$. The enzyme also oxidized primary alcohols of $\mathrm{C}_{8}-\mathrm{C}_{16}$, as shown in Table I. On the other hand, the purified enzyme reacted with aldehydes of $\mathrm{C}_{4}-\mathrm{C}_{7}$, the 
and $n$-butyraldehyde. The DCIP reduction was competitively inhibited by 1,4-benzoquinone and the apparent $K m$ values with the substrates, PEG 6000 and $n$-butyraldehyde, were both $1.4 \times 10^{-4} \mathrm{M}$ for DCIP, as calculated from Fig. 5 .

The results in this work together with those in the previous works have led us to the conclusion that PEG dehydrogenase is a novel enzyme which is quite different from other alcohol dehydrogenases reported so far (EC 1.1.1.1, 1.1.1.2, 1.1.1.71, 1.1.1.73, 1.1.1.164, 1.1.99.8 and alcohol dehydrogenase from acetic acid bacteria ${ }^{2,3)}$ ) as regards its coenzyme and/or its substrate specificity.

Acknowledgment. This study was supported in part by a Research Bounty grant from the Agricultural Chemical Society of Japan (1983).

\section{REFERENCES}

1) C. Anthony, "The Biochemistry of Methylotrophs," Academic Press Inc., New York, 1982, pp. 152 194.

2) M. Ameyama, K. Matsushita, Y. Ohno, E. Shinagawa and O. Adachi, FEBS Lett., 130, 179 (1981).

3) O. Adachi, E. Shinagawa, K. Matsushita and M. Ameyama, Agric. Biol. Chem., 46, 2859 (1982).

4) M. Ameyama, K. Osada, E. Shinagawa, K. Matsushita and O. Adachi, Agric. Biol. Chem., 45,
1889 (1981).

5) O. Adachi, E. Shinagawa, K. Matsushita, K. Nakashima and M. Ameyama, Proc. Annual Meeting Agr. Chem. Soc. Jpn., Sendai, 1983, p. 493.

6) M. Ameyama, E. Shinagawa, K. Matsushita and O. Adachi, Agric. Biol. Chem., 45, 851 (1981).

7) J. A. Duine, J. Frank, Jr. and J. K. Van Zeeland, FEBS Lett., 108, 443 (1979).

8) R. DeBeer, J. A. Duine, J. Frank, Jr. and P. J. Large, Biochim. Biophys. Acta, 622, 370 (1980).

9) M. Ameyama, M. Hayashi, K. Matsushita, E. Shinagawa and O. Adachi, Agric. Biol. Chem., 48, 561 (1984).

10) C. L. Lobenstein-Verbeek, J. A. Jongejan, J. Frank and J. A. Duine, FEBS Lett., 170, 305 (1984).

11) F. Kawai, M. Fukaya, Y. Tani and K. Ogata, J. Ferment. Tech., 55, 429 (1977).

12) F. Kawai, T. Kimura, M. Fukaya, Y. Tani, K. Ogata, T. Ueno and H. Fukami, Appl. Environ. Microbiol., 35, 679 (1978).

13) F. Kawai, T. Kimura, Y. Tani, H. Yamada and M. Kurachi, Appl. Environ. Microbiol., 40, 701 (1980).

14) F. Kawai, T. Kimura, Y. Tani, H. Yamada, T. Ueno and H. Fukami, Agric. Biol. Chem., 47, 1669 (1983).

15) F. Kawai, T. Kimura, Y. Tani and H. Yamada, Agric. Biol. Chem., 48, 1349 (1984).

16) K. Yamanaka and K. Matsumoto, Agric. Biol. Chem., 41, 467 (1977).

17) R. R. Eady and P. J. Large, Biochem. J., 123, 757 (1971).

18) M. Iwaki, T. Yagi, K. Horiike, Y. Saeki, T. Ushijima and M. Nozaki, Arch. Biochem. Biophys., 220, 253 (1983). 